\title{
A NEW NETWORK DESIGN FOR FORCING AIR TO PRODUCE COMPOST
}

\author{
M.A.M.Ahmed, ${ }^{2}$ M.Y.El.Ansary, ${ }^{1}$ M.A.Awad, ${ }^{1}$ M.T.Afify ${ }^{1}$
}

\begin{abstract}
\end{abstract}
The large amounts of the agricultural wastes remaining after the harvesting operations of the different crops represent a great challenge facing farmers, where they are estimated at 25 million tons annually. The farmers have to burn these wastes. This behavior leads to serious problems including the air pollution. Composting is considered the other choice to get rid of the agricultural wastes. It aims at both conservation of the environment, human safety and economically convenient production. The current investigation aims at:

1- Designing a network for forcing air through the compost pile to facilitate production of a good compost.

2- Studying the effect of both type of tube and rate of forcing air through it on the end-product, i.e. the compost beside of saving labor and time of production.

A direct ventilation system has been designed. It works on the basis that there is no turning but through forced air for the purpose of producing the compost from a mixture of rice straw and cattle dung at ratio of 2:1.

For fulfilling these purposes four networks were designed as follows:

1- Transversal system.

2- Longitudinal system.

3- Width and length system.

4- Reciprocal system.

The whole system was designed using PVC pipes with a $6.35 \mathrm{~cm}$ diameter, $3.9 \mathrm{~mm}$ thickness, a $262 \mathrm{~cm}$ length and a $130 \mathrm{~cm}$ width. The length and width were drilled with holes at equally divided distances of $30 \mathrm{~cm}$ (center to center) in two parallel rows.

The used types of tubes and the rate of air forced through them were evaluated according to the compost quality standards and guidelines which depend on determining quality parameters of the compost to be used in agriculture.

${ }^{1}$ Dep. of Agric. Eng. Fac. of Agric., Benha U.

${ }^{2}$ Agric. Eng. Res. Inst., Agric. Res. Center, Egypt.

Misr J. Ag. Eng., April 2010 
The obtained results indicated that the most suitable design for a network to produce compost of acceptable quality is the "width and length system" within which air is forced at rate of $0.0196 \mathrm{~m}^{3} /$ min.Moreover, a comparative study conducted among this system and both of natural conveyance system and self propelled machine systems illustrated that although the natural conveyance method gave the highest profit, yet the system depended on forcing air through width and length system seemed more preferable owing to the more favorable quality of the compost obtained by this method and also its relatively high profit.

\section{INTRODUCTION}

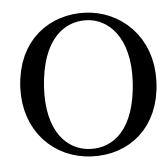
wing to the hazardous potential of using the ordinary mineral fertilizers in the soil and its surroundings (ground waters, drains, ...etc.), organic manure was found to be a suitable substitute for such mineral fertilizers (Abbas et al., 2006 and 2010).

Composting is regarded as a fully sustainable practice, since it aims at both conservation of the environment, human safety and economically convenient production (Sequi, 2000). The use of compost contributes to conservation by reducing both utilization of non-renewable resources and consumption of energy for waste treatment of chemical fertilizers. Composting indirectly also contributes to human safety by avoiding an improper fate or disposal of organic wastes. Furthermore, due to its low cost, compost is convenient to the farmer, but even more to the society by avoiding the use of expensive solutions for waste disposal (Bitton, 1999). A large amount of solid wastes remains after the harvesting operations of different crops. These residues are commonly moved to dumps, where they pose a threat of environmental pollution. Owing to the increase of agricultural wastes annually, the disposal systems became unable to meet their huge volumes. The field residues are now the main cause of the most critical problems in air, ground, and water pollution.

Egypt annually produces estimated crop residues weighting about 25 million tons on dry basis. The total amount of rice straw reaches about 3.6 million tons (dry matter) per year (Agric. Stat. $3^{\text {rd }}$. ed., 2002).

Different systems of composting wastes have been evaluated by several researchers. Manure and other organic wastes contain naturally occurring microorganisms capable of decomposing material anaerobically or aerobically. 
Although there exists a number of different composting methods and technologies, there are three main systems of centralized composting: aerated static pile process, windrow process and enclosed systems (Martin and Gershung, 1992, and Hong et. al., 1997).

Merkel (1981) reported that the rate at which organic matter decomposes is affected by the moisture content, $\mathrm{C} / \mathrm{N}$ ratio of the organic matter, temperature, availability of oxygen, $\mathrm{pH}$ value, and particle sizes.

Hansen et al. (1989) pointed out that there are about 20 factors that might potentially affect the composting process. The most important factors include carbon to nitrogen ratio $(\mathrm{C} / \mathrm{N})$, physical structure of the raw material, moisture content (M.C), $\mathrm{pH}$, temperature, and degree of aeration.

Two aeration rates $(0.850$ and $1.70 \mathrm{~L} / \mathrm{min})$ were investigated by Hatem and Ghaly (1994). The results indicated that both aeration rates produced good quality compost, but the aeration rate of $1.7 \mathrm{l} / \mathrm{min}$ produced less odors during the composting process. In all cases, the final products had similar appearance.

Eldridge and Shane (1993) pointed out that the forced aeration method of composting has relatively large start-up costs. Energy costs for operating the fans is off-set by reduction in windrow turning labor and associated costs. Savings occur in the form of reduced composting area requirements, rapid composting time, and potential reduction of odors.

Sartaj et al. (1995) stated that based on the method of aeration, composting technologies can be classified as natural aeration (NA), passive aeration (PA), forced aeration, termed windrow and in-vessel composting.

Sartaj et al. (1997) stated that in essence, during composting, microorganisms consume oxygen, nutrients, and organic matter to produce new cells, stable organic residues, energy in the form of heat, carbon dioxide, water, ammonia, and some minor end products.

For efficient composting, operational parameters such as available nutrients, moisture, temperature, aeration, and $\mathrm{pH}$ have to be optimized to create an environment that will maximize aerobic thermophilic activity (Das and Keener, 1997). 
Walker et al. (1999) stated that the differences between these classes of technology are largely based on how intensely the heterogeneous, poly phases environment is managed to achieve the desired perfection. Windrows are the simplest and the least intensively managed. The two process variables are most frequently used to manage this natural process with aeration rate missing frequency.

Gouin et al. (1992) reported that aerobic composting consumes a large amount of oxygen. In addition for providing oxygen, aeration removes heat, under vapor and other gases trapped within the composting materials.

The required air flow rates depend on how aeration is managed. Therefore the current investigation was conducted to provide an efficient system for aeration of the composting pile aiming at achieving manufacture of compost characterized by a good quality on one hand and of a high economic value on the other hand.

\section{MATERIALS AND METHODS}

\section{Materials.}

\section{1-Cattle dung.}

Basic characteristics of this material are shown in Table (1).

Table (1): Basic characteristics of the cattle dung used in the experimental work.

\begin{tabular}{|c|c|c|c|c|c|c|c|c|c|c|}
\hline $\begin{array}{l}\text { pH } \\
1: 10\end{array}$ & $\begin{array}{c}\text { Moisture } \\
\text { content } \\
\% \\
\end{array}$ & $\begin{array}{c}\text { Organic } \\
\text { matter } \\
\% \\
\end{array}$ & $\begin{array}{c}\text { Organic } \\
\text { carbon } \\
\% \\
\end{array}$ & $\begin{array}{c}\text { Dry } \\
\text { matter } \\
\%\end{array}$ & $\begin{array}{c}\text { Total } \\
\mathbf{N} \\
\mathbf{\%} \\
\end{array}$ & $\begin{array}{c}\text { Total Fe } \\
\mathrm{mg} / \mathrm{kg}\end{array}$ & $\begin{array}{l}\text { Total Mn } \\
\text { mg/kg }\end{array}$ & $\begin{array}{c}\text { Total Zn } \\
\mathrm{mg} / \mathrm{kg}\end{array}$ & $\underset{\mathrm{mg} / \mathrm{kg}}{\text { Total } \mathrm{Cu}}$ & $\begin{array}{l}\text { B.D. } \\
\mathrm{kg} / \mathrm{m}^{3}\end{array}$ \\
\hline 8.70 & 82 & 82.00 & 43.90 & 18.00 & 0.70 & 145 & 45 & 29 & 25 & 378 \\
\hline
\end{tabular}

2- Rice straw.

Rice straw was collected from the field after harvesting operation. It was dried and pulverized into small pieces (3-5, 5-7 and 7-10 cm length) before mixing preparation. Table (2) shows the basic characteristics of the used rice straw.

Table (2): Basic characteristics of the rice straw used in the experimental work.

\begin{tabular}{|l|c|c|c|c|c|c|c|c|c|c|}
\hline $\begin{array}{l}\text { pH } \\
1: 10\end{array}$ & $\begin{array}{c}\text { Moisture } \\
\text { content } \\
\%\end{array}$ & $\begin{array}{c}\text { Organic } \\
\text { matter } \\
\%\end{array}$ & $\begin{array}{c}\text { Organic } \\
\text { carbon } \\
\%\end{array}$ & $\begin{array}{c}\text { Dry } \\
\text { matter } \\
\%\end{array}$ & $\begin{array}{c}\text { Total } \\
\mathbf{N} \\
\%\end{array}$ & $\begin{array}{c}\text { Total Fe } \\
\mathbf{m g} / \mathbf{k g}\end{array}$ & $\begin{array}{c}\text { Total Mn } \\
\mathbf{m g} / \mathbf{k g}\end{array}$ & $\begin{array}{c}\text { Total Zn } \\
\mathbf{m g} / \mathbf{k g}\end{array}$ & $\begin{array}{c}\text { Total Cu } \\
\mathrm{mg} / \mathrm{kg}\end{array}$ & $\begin{array}{c}\text { B.D. } \\
\mathbf{~ k g} / \mathrm{m}^{3}\end{array}$ \\
\hline $\mathbf{6 . 3 7}$ & $\mathbf{8 . 2 0}$ & $\mathbf{8 2 . 1 9}$ & $\mathbf{4 7 . 6 7}$ & $\mathbf{9 1 . 8 0}$ & $\mathbf{0 . 6 1 2}$ & $\mathbf{6 3 2}$ & $\mathbf{6 7}$ & 103 & $\mathbf{4 1}$ & $\mathbf{7 2}$ \\
\hline
\end{tabular}


All laboratory analyses were executed according to ASAE (1997) standard methods. Samples were randomly taken from raw materials (dung and rice straw). Also, four samples from each pile were taken at $50 \mathrm{~cm}$ depth and distances $75 \mathrm{~cm}$ apart along pile at the beginning and end of experiment.

The moisture content was determined by comparing the weight of a sample before and after drying at $70 \mathrm{C}^{\circ}$ for 48 hours, in an electrical oven (Electrical oven, Model N3p, W. Germany). The moisture content (M.C \%) was determined as follows:

Moisture content, (M.C \%) $=\mathrm{M}_{\mathrm{w}}-\mathrm{M}_{\mathrm{d}} / \mathrm{M}_{\mathrm{w}} \times 100$

Where:

$M_{w}=$ weight of the wet sample; $M_{d}=$ weight of the dry sample.

$\mathrm{C} / \mathrm{N}$ ratio was calculated after the amounts of carbon and total nitrogen in the composting media were assessed.

The bulk density is the dry mass of the material per unit volume of solids and voids occupied by the original material. Bulk density can be found from the following equation (ASAE Standard Methods 1997).

Bulk density $\left(\mathrm{g} / \mathrm{cm}^{3}\right)=\left[\left(\right.\right.$ density $\left(\mathrm{g} / \mathrm{cm}^{3}\right) \times$ dry matter $\left.\left.(\%)\right)\right]$

A direct ventilation system was designed to work without turning, but through forced air for the purpose of producing the compost according to the following steps:

1-The raw materials were mixed at a ratio of 2:1 (rice straw to cattle dung).

2- A compost substrate was formed and produced at site by the mechanical aeration method with a $3.4 \mathrm{~m}$ length, $1.8 \mathrm{~m}$ width and $10 \mathrm{~cm}$ height.

3-The piping networks which were designed for this study (see Fig.1) were placed over the above mentioned substrate.

4- The mixed raw materials were placed directly over the piping networks and the formed piles having a $1.05 \mathrm{~m}$ height and covered with a $10 \mathrm{~cm}$ thick compost layer.

5- Previously calculated air flow was forced through the network daily, using a compressor with the following rates: $0.0098,0.0196$ and $0.0294 \mathrm{~m} / \mathrm{min}$.

\section{The networks were designed as follows:}

1- Transversal system.

3- Width and length system.
2- Longitudinal system.

4- Reciprocal long system.

The whole system was designed using PVC pipes with a $6.35 \mathrm{~cm}$ diameter, 3.9 $\mathrm{mm}$ thickness, a $262 \mathrm{~cm}$ length and a $130 \mathrm{~cm}$ width. The length and width were drilled with holes at equally divided distances of $30 \mathrm{~cm}$ (center to center) in two parallel rows, these pipes can have a pressure load up to 20 bar as shown in Figure (1). 


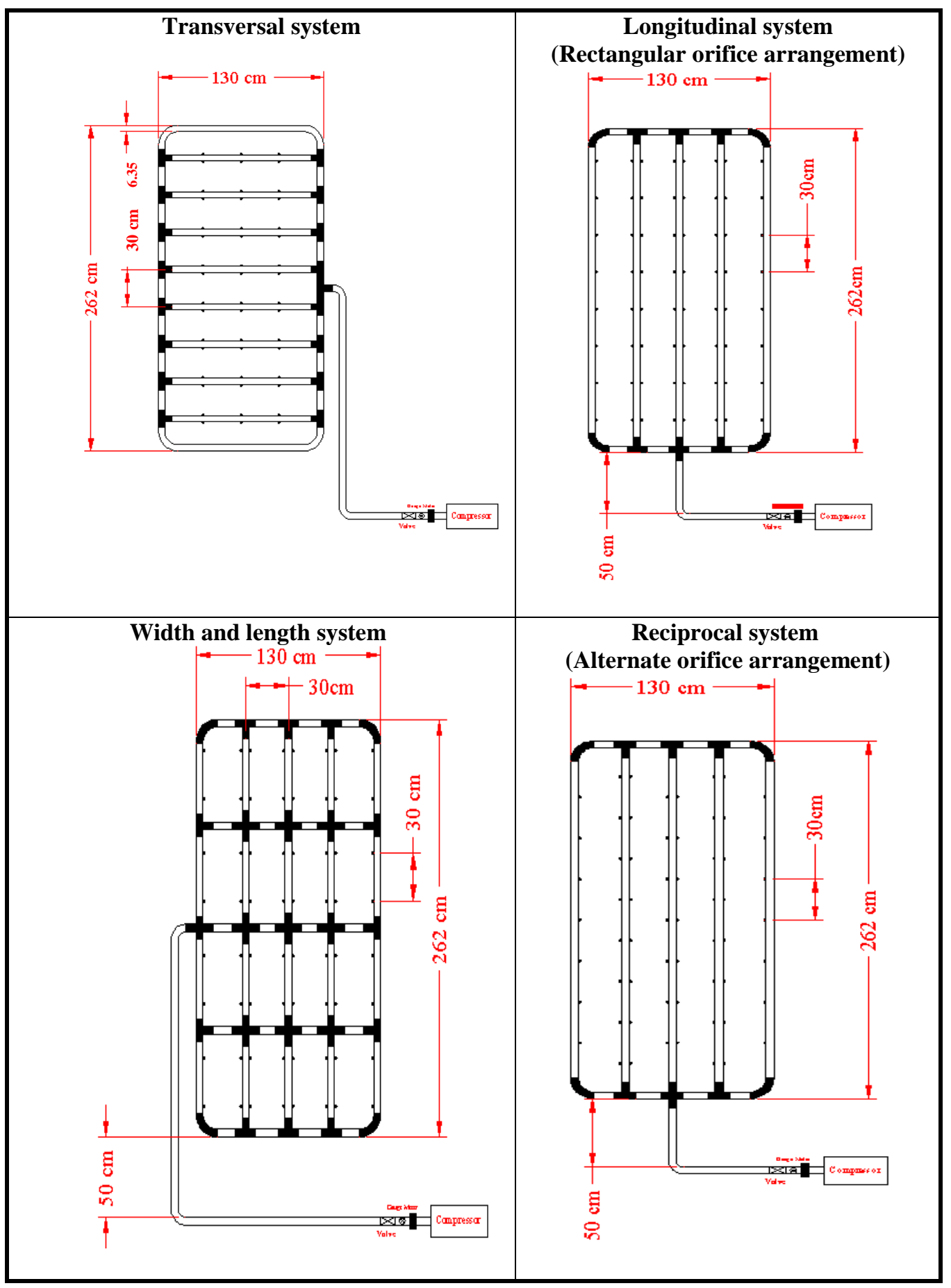

Figure (1): Schematic design of the different networks used in the current study. 


\section{1-Volume of material in the pile:}

Volume $=$ manure + straw, $\mathrm{m}^{3}$

\section{2- Length of pile:}

Area $=$ height $\times$ width

Length of pile $=$ Volume $\div$ Area

\section{3- Estimated airflow rate:}

Dry mass of manure $=$ Wet mass $\times 0.15, \mathrm{~kg}$.

Estimated airflow rate $=\mathrm{M} \times \mathrm{q}$

Where:

M: dry mass in tons.

q: air flow rate in cu. m. per min per ton dry mass.

\section{4- Pipe specifications:}

Estimated pipe size:

$\mathrm{A}=\frac{q}{v}$,

Where:

A: cross-sec. area, $\mathrm{m}^{2}$

q: rate of flow, $\mathrm{m} 3 / \mathrm{min}$

v: allowed air vel., $600 \mathrm{~m} / \mathrm{min}$

- Diameter $=(4 \mathrm{~A} / \boldsymbol{л})^{\mathbf{1 / 2}}, \mathrm{m}$

- Perforated pipe length $=$ pile length $-(2 \times$ pile height $)$

\section{5- Estimated hole diameter:}

Hole diameter $=\left(D^{2} \times s / L\right)^{1 / 2}$

Where:

$\mathrm{D}=$ pipe diameter.

$\mathrm{L}=$ pipe length.

$\mathrm{s}=$ hole spacing. ( units have to be homogeneous)

A comparative study was conducted between the forced aeration system executed herein and the natural conveyance system conducted by the authors (Ahmed, 2010) and self propelled agitation system (Abd-ElMottaleb and Kotob, 2005). 


\section{RESULTS AND DISCUSSION}

Effect of both time and aeration flow rate on characteristics of the produced compost:

\section{A-Performance of the composting system using forced air through transversal system:}

Data presented in Fig.(2) reveal that with processing period of composting, the $\mathrm{pH}$ values were slightly affected. However, increasing composting period resulted in corresponding increases in values of bulk density and total nitrogen percentage. On the other hand, the increase in period of composting was associated with corresponding decreases in values of moisture $\%$, and the $\mathrm{C} / \mathrm{N}$ ratio of the compost.

Such effects occurred regardless of rate of the forced air, which seemed to be of no or of slight effect on values of organic matter percentage, whose values were $29.39,29.90$ and $29.93 \%$ at the forced air rates of 0.0098 , 0.0196 and $0.0294 \mathrm{~m}^{3} / \mathrm{min}$.

Almost negligible increasing occurred in organic carbon percentage whose values were $16.33,16.61 \%$ and 16.72 , respectively.

On the other hand, increasing rate of the forced air seemed to be of more pronounced effects on bulk density whose values increased from 398.96 $\mathrm{kg} / \mathrm{m}^{3}$ at a forced air rate of $0.0098 \mathrm{~m}^{3} / \mathrm{min}$ to $429.18 \mathrm{~kg} / \mathrm{m}^{3}$ at a forced air rate of $0.0294 \mathrm{~m}^{3} / \mathrm{min}$. Likewise, total nitrogen percentage increased from 0.96 to $1.01 \%$ upon increasing the forced air rate from 0.0098 up to $0.0294 \mathrm{~m}^{3} / \mathrm{min}$. The decrease in $\mathrm{C} / \mathrm{N}$ ratio, the increase in the values of the bulk density and the total nitrogen percentage are among the desired favorable properties of the compost.

Accordingly, it can be concluded that increasing rate of the forced air might be of important role in improving properties of compost and is recommended to achieve such a goal.

\section{B-Performance of the composting system using forced air through longitudinal system:}

Data illustrated graphically in Fig. (2) reveal that increasing rate of the forced air resulted in increase in each of bulk density, total nitrogen \%.On the other hand values of moisture $\%$ and $\mathrm{C} / \mathrm{N}$ ratio tended to decrease obviously. 
The effects of time of composting on values of the above mentioned parameters seemed to be similar to those already mentioned under the air forced through transversal system i.e. : values of bulk density, total nitrogen and bulk density increased whereas values of $\mathrm{C} / \mathrm{N}$ ratio and moisture $\%$ decreased with progressing period of composting.

These results assured the aforementioned ones which confirmed the important role of increasing rate of forced air on increasing the total nitrogen $\%$ and at the same time decreasing the $\mathrm{C} / \mathrm{N}$ ratio. $\mathrm{C}$ - Performance of the composting system using forced air through width and length system:

By progressing time of composting values of the measured parameters seemed very close to what occurred with the previously mentioned systems of aeration. However, small variations could be observed in magnitudes of the final values of these parameters where some values tended to be higher such as the moisture content and $\mathrm{C} / \mathrm{N}$ ratio whereas others tended to be smaller e.g. total nitrogen \% (Fig.,2).

\section{D- Performance of the composting systems using forced air through the reciprocal tubes:}

Data illustrated graphically in Fig.(2) reveal that time of composting and rate of the air forced through the reciprocal tubes were of obvious effects on the most important parameters of the manufactured compost similar, to a great extent, to those attained due to forcing the air through the transversal, longitudinal, width and length and reciprocal systems. However, relatively lower values were obtained for the bulk density, and on the other hand, relatively higher ones were obtained for values of the total nitrogen percentage. 

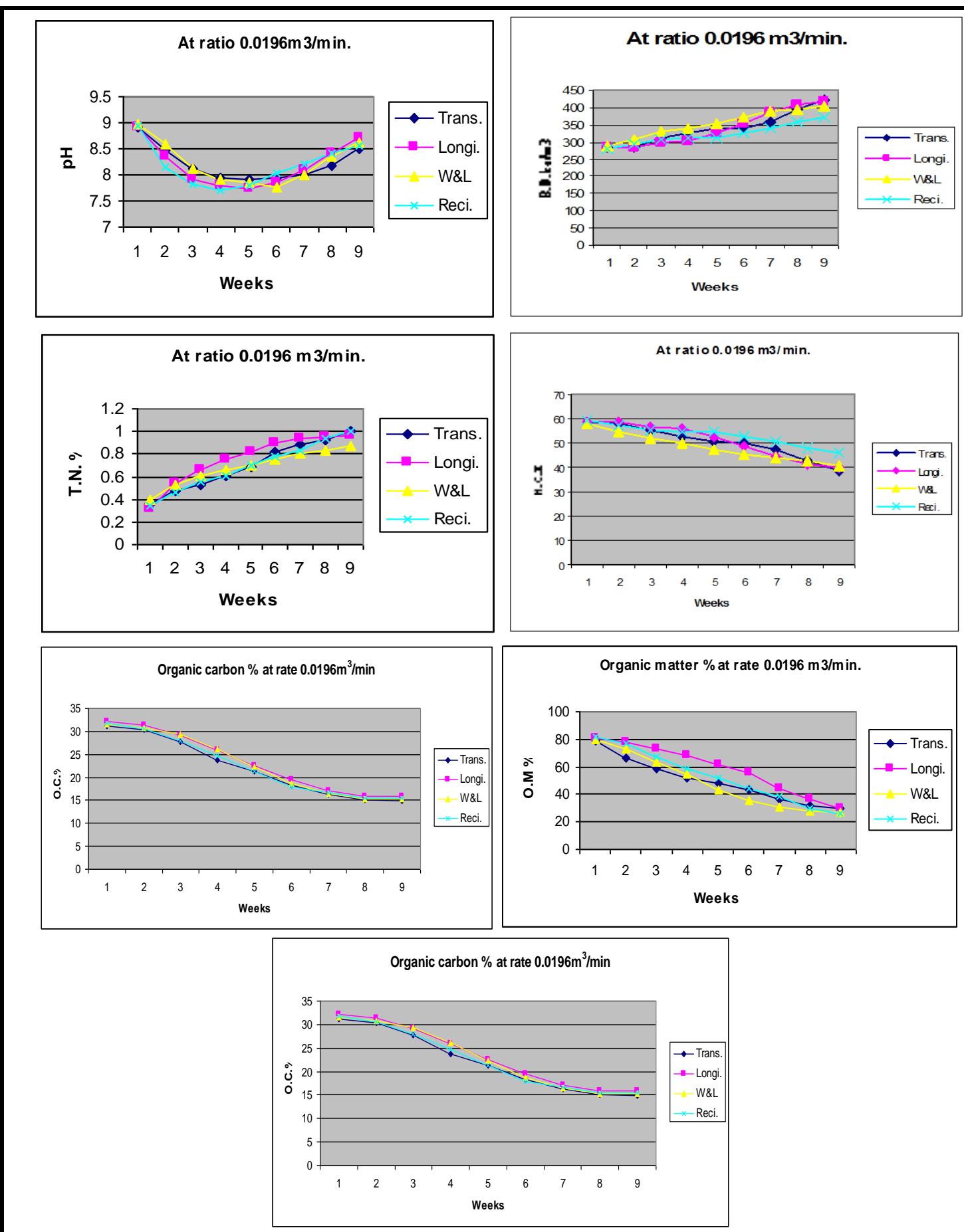

Figure (2):Effect of period of composting and rate of forced air through different types of tubes on the most important parameters of the produced compost. 


\section{Effect of type of air forcing system on characteristics of the produced compost:}

A- At rate of forced air of $0.0098 \mathrm{~m}^{3} / \mathrm{min}$.

According to $\mathrm{pH}$ value of the mature compost at end of composting period, types of the used aeration system can be arranged descendingly in the following order:

Width and length system (8.81) > reciprocal system (8.70) > longitudinal system (8.63) > transversal system (8.59).

According to values of the bulk density, the order was longitudinal system (401.68) > width and length system (398.02) > transversal system (388.9) $>$ reciprocal system $\left(355.17 \mathrm{~kg} / \mathrm{m}^{\mathbf{3}}\right)$.

Values of the moisture content, the reciprocal system (48.6) > transversal system (43.71) > width and length system (42.40) > longitudinal system $(41.87 \%)$.

Values of total nitrogen \%, transversal system (0.96) longitudinal system $(0.94)>$ reciprocal system $(0.902)>$ width and length system $(0.732 \%)$.

$\underline{\mathrm{C} / \mathrm{N} \text { ratio, }}$, width and length system $(17.50)>$ reciprocal system $(16.53)>$ longitudinal system (15.89) > transversal system (14.57\%).

B- At rate of forced air of $0.0196 \mathrm{~m}^{3} / \mathrm{min}$.

According to $\mathrm{pH}$ value of the mature compost at end of composting period, longitudinal system $(8.72)>$ width and length system (8.62) > reciprocal system (8.57) > transversal system (8.49).

The bulk density, transversal system (424.27) > longitudinal system (416.67) > width and length system (403.54) > reciprocal system $(371.76$ $\left.\mathrm{kg} / \mathrm{m}^{3}\right)$.

According to moisture content, the reciprocal system (46.2) > width and length system (41.6) > longitudinal system (39.7) > transversal system $(38.6 \%)$.

According to value of total nitrogen $\%$, transversal system $=$ reciprocal system (1.0) > longitudinal system (0.96) > width and length system (o.87 \%).

According to the $\mathrm{C} / \mathrm{N}$ ratio, width and length system (20.08) > reciprocal system $(16.40)>$ longitudinal system $(15.4)>$ transversal system $(14.9 \%)$. C- At rate of forced air of $0.0294 \mathrm{~m}^{3} / \mathrm{min}$.

According to $\mathrm{pH}$ value of the mature compost at end of composting period: 
Longitudinal system (8.76) > width and length system (8.71) > reciprocal system (8.55) > transversal system (8.47).

According to values of the bulk density:

Transversal system (429.18) > longitudinal system (421.79) > width and length system $(421.23)>$ reciprocal system $\left(381.5 \mathrm{~kg} / \mathrm{m}^{3}\right)$.

According to values of the moisture content:

The reciprocal system (44.8) > width and length system (39.04) > longitudinal system (38.96) > transversal system (37.89\%).

According to total nitrogen \%:

Reciprocal system (1.04) > transversal system (1.01) > longitudinal system $(0.97)>$ width and length system $(0.88 \%)$.

According to the $\mathrm{C} / \mathrm{N}$ ratio:

Width and length system (17.42) > reciprocal system (16.50) > longitudinal system(14.89) > transversal system (14.78\%).

Evaluation of the used types of air forcing system and rates of the air flow according to the compost quality.

There are critical values of quality parameters of the compost to be used in agriculture. These values are chosen to reflect the widest possible range of end - user concerns and applications.

Conformance of these quantitative quality parameter values is achievable under reasonable compost process conditions. However, there is no simple way to give fixed or certain values concerning compost quality standards as they vary in the various countries.

In this research paper, it was suggested to take into consideration the most important characters of the compost that would affect soil properties and hence plant grown thereon. The chosen characteristics are the organic matter $\%$, total nitrogen $\%, \mathrm{C} / \mathrm{N}$ ratio, $\mathrm{pH}$ and moisture content $\%$. Different, critical values were reported for these parameters, however, generally they went almost to agree about some magnitudes such as $>35 \%$ (for organic matter\%) $>0.9 \%$ ( for total nitrogen \%), $<25$ ( for $\mathrm{C} / \mathrm{N}$ ratio), values ranging from $6.5-8.5$ (for $\mathrm{pH}$ ), > $35 \%$ ( for moisture \%) and $395-420 \mathrm{~kg} / \mathrm{m}^{3}$ (for bulk density)( Conti, et al.1996 and Hong et al.1985). 
From the obtained results, it could be deduced that the most suitable design for network to produce compost of acceptable quality is "width and length system" within which air is forced at rate of $0.0196 \mathrm{~m}^{3} / \mathrm{min}$.

\section{A comparative study among the forced aeration systems, natural conveyance system and self propelled agitator:}

Table (3) shows the relationship between composting system and maturity period, and the corresponding production specification. The aforementioned standard guidelines indicated superiority of the width and length system over the natural conveyance one and the self propelled machine system. The longest period required for maturing the compost was 77 day for natural conveyance, meanwhile the shortest period was 56 day only for the width and length system.

Table(3): A comparison among the physical and chemical properties of the produced composts under different production systems.

\begin{tabular}{|c|c|c|c|c|c|c|c|c|c|}
\hline \multirow[t]{2}{*}{ System } & \multirow{2}{*}{$\begin{array}{c}\text { Maturity } \\
\text { period }\end{array}$} & \multicolumn{6}{|c|}{ Production specifications } & \multirow[b]{2}{*}{ C/N ratio } & \multirow[b]{2}{*}{ O.M\% } \\
\hline & & pH & M.C\% & $\begin{array}{l}\text { T.N } \\
\%\end{array}$ & O.C\% & D.M\% & B.D kg/m $\mathrm{m}^{3}$ & & \\
\hline Width and length system & 56 & 8.62 & 41.60 & 0.87 & 15.20 & $\mathbf{5 8 . 4 0}$ & 407.60 & 20.01 & 27.20 \\
\hline $\begin{array}{l}\text { Natural conveyance } \\
\text { system }\end{array}$ & 77 & 8.76 & 46.18 & 0.86 & 14.50 & $\mathbf{5 3 . 8 2}$ & 373.94 & 16.40 & 27.95 \\
\hline $\begin{array}{l}\text { Self propelled machine } \\
\text { system }\end{array}$ & 60 & 8.70 & 49.90 & 0.85 & $20 . .40$ & 46.90 & 372.83 & 18.00 & 30.05 \\
\hline
\end{tabular}

Table (4) represents a comparative study among the actual costs for production of compost under the different aforementioned systems which were 10.19 LE\h, 32.01 LElh and 126.44 LElh for the natural conveyance aeration, width and length system (which is the best systems in this study) and self propelled agitator conducted by the authors elsewhere, (AbdEIMottaleb and Kotob, 2005). The lowest costs concerned the natural conveyance aeration system while the highest costs concerned the self propelled machine. This is probably due to its highest initial costs. 
Table (4): A comparison between the actual costs for compost production under the different production systems.

\begin{tabular}{|c|c|c|c|}
\hline Systems & $\begin{array}{c}\text { Natural } \\
\text { Conveyance } \\
\text { aeration }\end{array}$ & $\begin{array}{l}\text { Width and } \\
\text { Long system }\end{array}$ & $\begin{array}{c}* \\
\text { Self propelled } \\
\text { machine }\end{array}$ \\
\hline \multicolumn{4}{|l|}{ Items } \\
\hline$\frac{\text { Fixed cost: }}{\text { Machine price }}$ & 3511 L.E & 6011 L.E & 1000,000 L.E \\
\hline Depreciation & $3.15 \mathrm{~L} . \mathrm{E} / \mathrm{h}$ & 5.41 L.E/h & 36.60 L.E/h \\
\hline Interest & 1.74 L.E/h & 2.98 L.E $/ \mathrm{h}$ & 19.83 L.E/h \\
\hline Taxes and insurance & $0.70 \mathrm{~L} . \mathrm{E} / \mathrm{h}$ & $1.2 \mathrm{~L} . \mathrm{E} / \mathrm{h}$ & $8.0 \mathrm{~L} . \mathrm{E} / \mathrm{h} 1$ \\
\hline Total fixed cost & 5.59 L.E/h & 9.59 L.E/h & 64.44 L.E/h \\
\hline \multicolumn{4}{|l|}{ Variable cost: } \\
\hline Fuel: Gas or Elect. & ------ & 9.12 L.E/h & 17.1 L.E/h \\
\hline Oils & ------- & 5.30 L.E $/ \mathrm{h}$ & 9.8 L.E/h \\
\hline Lubricates & ------ & 0.25 L.E $/ \mathrm{h}$ & $1.0 \mathrm{~L} . \mathrm{E} / \mathrm{h}$ \\
\hline Maintenance & 0.75 L.E/h & $1.30 \mathrm{~L} . \mathrm{E} / \mathrm{h}$ & 10.22 L.E/h \\
\hline Repairs & ------- & 2.60 L.E/h & 20.03 L.E/h \\
\hline Labors & $3.85 \mathrm{~L} . \mathrm{E} / \mathrm{h}$ & $3.85 \mathrm{~L} . \mathrm{E} / \mathrm{h}$ & $3.85 \mathrm{~L} . \mathrm{E} / \mathrm{h}$ \\
\hline Total variable cost & 4.60 L.E $/ \mathrm{h}$ & 22.42 L.E/h & $62.00 \mathrm{~L} . \mathrm{E} / \mathrm{h}$ \\
\hline Actual cost & 10.19 L.E/h & 32.01 L.E/h & 126.44 L.E/h \\
\hline
\end{tabular}

*Abd-El-Mottaleb and Kotob (2005).

Table (5) revels that the natural conveyance aeration method gave the highest profit $194.40 \%$. Meanwhile, the self propelled method gave the lowest profit, due to the increase in the capital cost.

The aforementioned comparison reveals that although the natural conveyance system could record the highest economic profit, yet the width and length system might be considered preferable because it produced a compost of higher quality beside its economic profit which is near that attained due to the natural coverage aeration system.

Table (5): Economic parameters to compare between compost types.

\begin{tabular}{|c|c|c|c|c|}
\hline \multicolumn{1}{|c|}{ Item } & Unit & $\begin{array}{c}\text { Width and length } \\
\text { system }\end{array}$ & $\begin{array}{c}\text { Natural conveyance } \\
\text { aeration }\end{array}$ & $\begin{array}{c}\text { Self propelled } \\
\text { agitator }\end{array}$ \\
\hline Total cost & LE/h & $\mathbf{3 2 . 0 1}$ & $\mathbf{1 0 . 1 9}$ & $\mathbf{1 2 6 . 4 4}$ \\
\hline Total income & LE/h & $\mathbf{8 0 . 0 0}$ & $\mathbf{3 0 . 0 0}$ & 150.00 \\
\hline Net income & LE/h & $\mathbf{5 7 . 9 9}$ & 19.81 & 23.56 \\
\hline
\end{tabular}




\section{REFERENCES}

Abbas, H.H., E.H.A. Noufal, I.M. Farid and I.M.E. Ali (2006) Organic manuring and bio - fertilization approaches as potential economic and safe substitutes for mineral nitrogenous fertilization. Egypt. J. Soil Sci., 46 (2):219 - 135.

Abbas, H.H., I.M.Farid and Ali, M.M.E. (2010) Growth of maize and its uptake of some macro and micronutrients under different untraditional fertilization treatments. Minia $2^{\text {nd }}$ Conf. Agric. Environ. Sci., March 22-24,2010.

Abd-EIMottaleb,A.F. and Kotob,M.M.(2005)"Engineering and economical studies on compost agitation systems under Egyptian conditions " Misr J. Ag. Eng., 22(2): 612 - 634.

Ahmed, A. M. (2010) "Study of compost application for clay soil under surface and subsurface drip irrigation systems" undergoing Ph.D. Th., Ag. Eng., Fac. Ag. Benha U.

ASAE, standards D241.4 (1997) "Methods of determining density, specific gravity, and mass moisture" ASAE st. Joseph, Michigan.

Bitton G. (1999). Public health aspects of wastewater and sludge disposal, p. 347. In Bitton G (ed.) Wastewater microbiology. JohnWiley \& Sons Inc.,New York.

Conti, F., Urbini, G., Zorzi, G. and Bertoldi,M. de(ed.)(1996) Basic processing technologies and composting plant design in Italy. The Sci. composting: part 2,: 958-972.

Das, K. and Keener, H.M. (1997) " Numerical Model for the dynamic Simulation of large scale composting system" Transaction of the ASAE, 40 (4):1179-1189.

Eldridge, R.; Collins, J. and Shan, C.P. (1993) "Development of composting recipe for swine. Presentation at I. summer Mtg. sponsored by ASAE, Spokane center, Washi., paper no.934033.

Hansen, R. C. , Keener, H. M. and Hoitink, H. A. J. (1989)."Poultry manure composting. An exploratory study".Trans. ASAE, 32 (6) : $2152-2157$. 
Hatem, M. H.; and Gay , A. E. (1994). " composting of municipal solid waste " Misr, J. Agric. Eng., 11 (2) : 548 - 558.

Hong, J. H.; Park, K. J. and Sohn, B. K.(1997). " Effect of composting heat from, intermittent aerated static pile on the elevation of underground temperature ". Appl. Engi. Ag.. Vol. 13 ( 5 ) : 679 683.

Hong , J. H. ; Matsuda , J. and Ikeuehi , Y. ( 1985 ) " An overview of compost maturity during solid composting in mixture of dairy manure and crop residues ". Soci. Ag. Structures, Japan, 16 ( 1): 6 13 .

Inbar, Y. , Hadar, Y. and Chen, Y. (1993). "Recycling of cattle manure: The composting process and characterization of maturity". Environ. Qua., (4): 857 - 863.

Merkel, J.A. (1981). "Managing livestock wastes" AVI Publ.Co., Westport Conn. : 306-324.

Martin, D. L. and G. Gershung (1992) The Rodale Book of composting. Rodal press, Emmaus, Pennsylvania.

Rynk, R. (1992). " On-farm composting handbook", Northeast Reg. Agr. Eng. Service, Ithaca, N. Y. :54

Seki, H. (2000). " Stochastic modeling of composting processes with batch operation by the Fkker - Plant equation Trans. ASAE, 43 (1): 169 179.

Sartaj, M.; Fernandes, L. and Patni, N.K. (1995). " Influence zone of aeration pipes and temperature variations in passively aerated composting of manure slurries Trans. ASAE, 38 (6): 1835 - 1841.

Sartaj, M.; Fernandes, L. and Patni, N.K.(1997). Performance of forced , passive, and natural aeration methods for composting manure slurries. Trans. ASAE, 40 ( 2 ) : $457-463$.

Walker, L. P.; Nock, T. D.; Gossett, J. M. and VanderGheynst, J. S. (1999). " The role of periodic water addition in managing moisture limitations during high-solids aerobic decomposition " Process Biochem., 34 (6-7): $601-612$. 


\section{BIOLOGICAL ENGINEERING}

\section{APPENDIX}
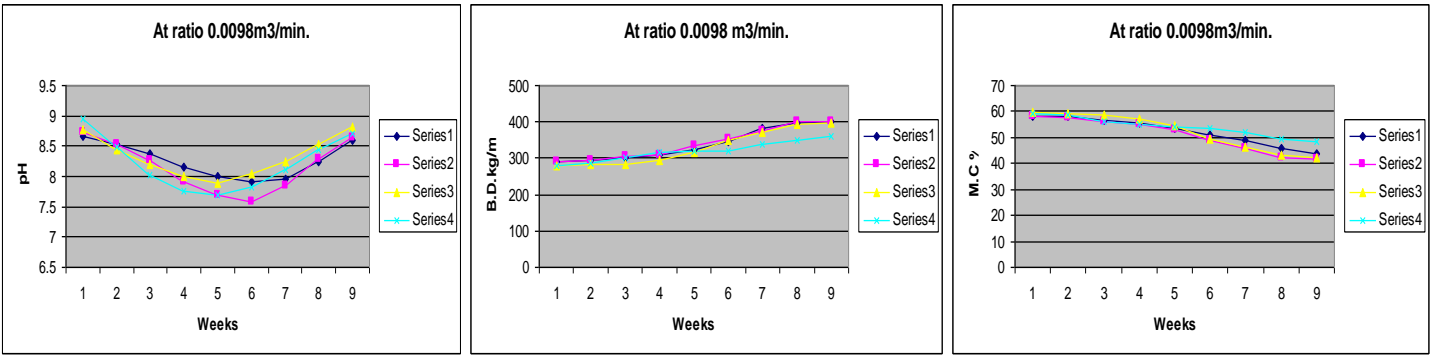

Organic carbon \% at rate $0.0098 \mathrm{~m}^{3} / \mathrm{min}$
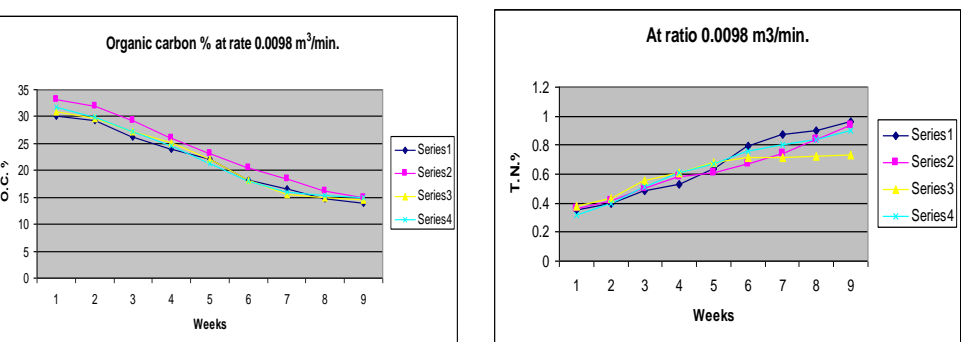

At rate of $0.0196 \mathrm{~m} 3 / \mathrm{min}$
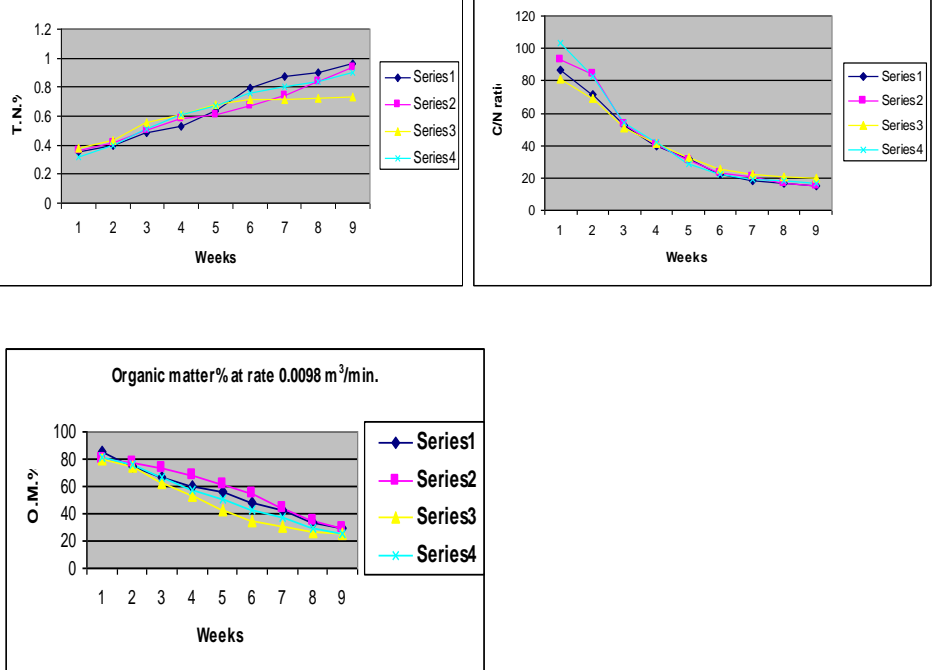


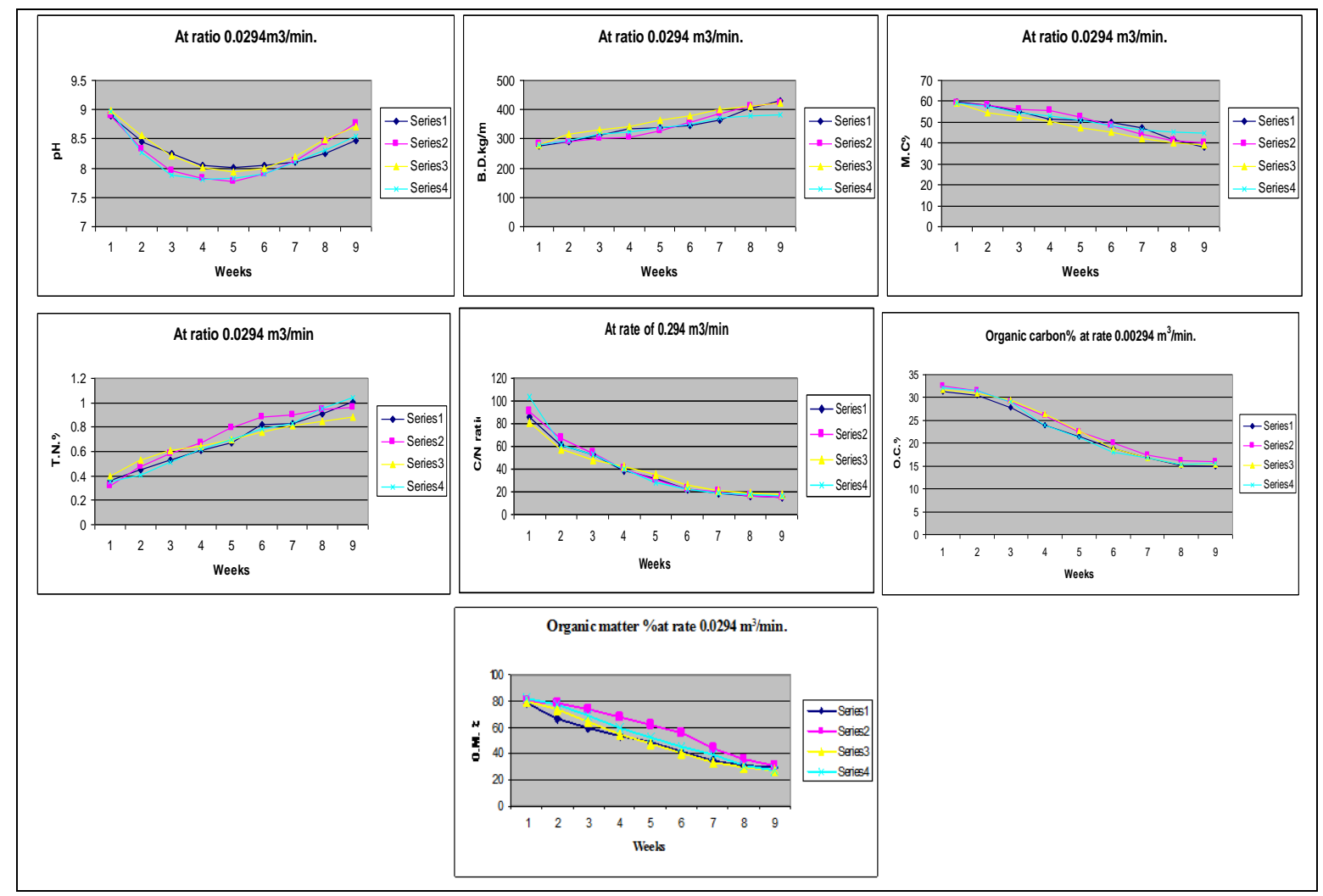

\section{Continuation of Fig.2}

\section{الملخص العربي}

تصميم جديد لشبكات دفع الهواء لإنتاج السماد العضوي( الكومبوستب)

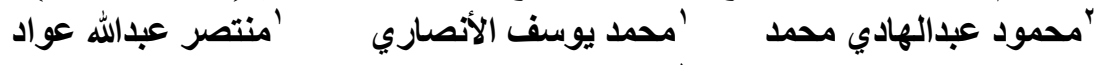

$$
\text { ' محمد تهامي عفيفي 'مديف الأصناري }
$$

$$
\text { الهـف الرئيسى من هذا البحث : }
$$

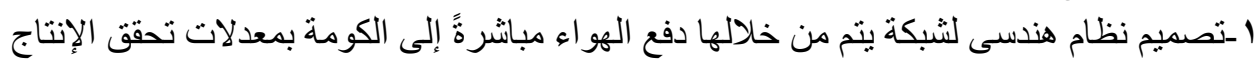

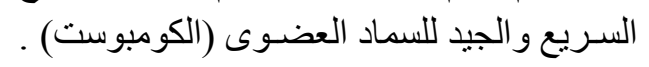

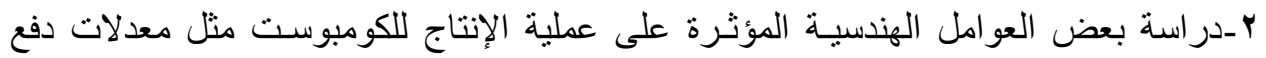

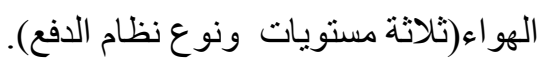

1قسم الهندسة الزر اعية ـ كلية الزر اعة - جامعة بنها. 2معهد بحوث الهندسة الزر اعبة - مركز البحوث الزية الزر اعية. 
خطوات تنفيذ البحث :

وقد تم تصميم وتصنيع وتركيب أربع شبكات منماثلة فى المحيط الخارجى كنماذج تجريبية كالآتى :

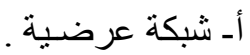
ب- شبكة طولية. جـ شبكة عرضية وطية وطولية.

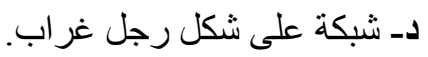

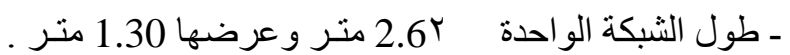

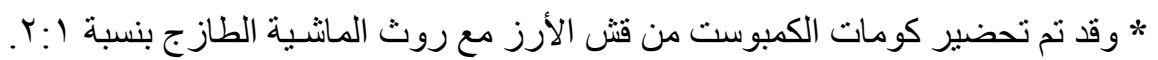

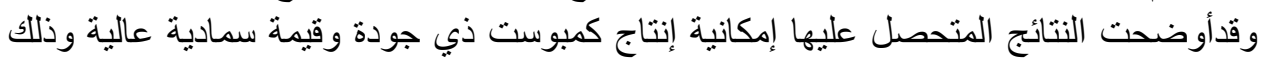

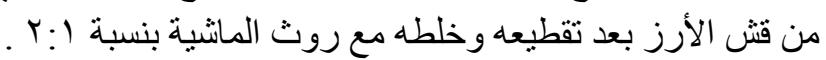

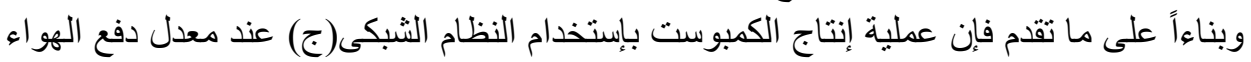
0.0196 m²3\%min.

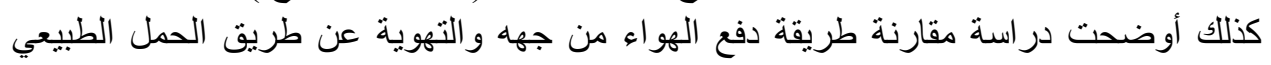

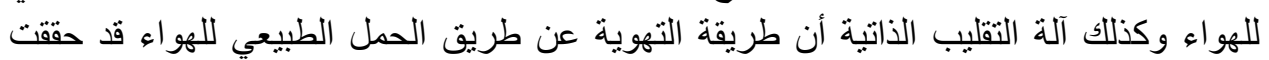

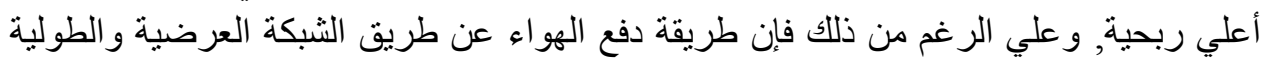

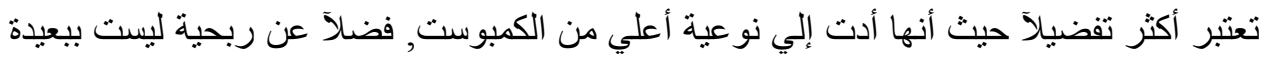

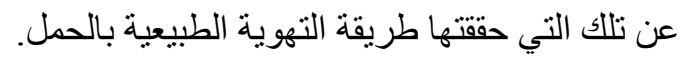

